\title{
Correction: Lassa hemorrhagic fever in a late term pregnancy from northern Sierra Leone with a positive maternal outcome: case report
}

\author{
Luis M Branco ${ }^{1,2}$, Matt L Boisen ${ }^{3}$, Kristian G Andersen ${ }^{4}$, Jessica N Grove ${ }^{1}$, Lina M Moses ${ }^{1}$, Ivana J Muncy ${ }^{3}$, \\ Lee A Henderson ${ }^{5}$, John S Schieffellin ${ }^{6}$, James E Robinson ${ }^{6}$, James J Bangura, ${ }^{7,8}$, Donald S Grant ${ }^{9,7}$, \\ Vanessa N Raabe ${ }^{10}$, balu M Fonnie ${ }^{9}$, Eleina M Zaitsev ${ }^{4,11}$, Pardis C Sabeti ${ }^{4,11}$ and Robert F Garry ${ }^{1 *}$
}

\section{Correction}

After publication of this work [1], we noted that we inadvertently failed to include the complete list of all coauthors. The full list of authors has now been added and the Authors' contributions and Competing interests section modified accordingly.

\begin{abstract}
Author details
'Department of Microbiology and Immunology, Tulane University, New Orleans, Louisiana, USA. ${ }^{2}$ Autoimmune Technologies, LLC, New Orleans, Louisiana, USA. ${ }^{3}$ Corgenix Medical Corporation, Broomfield, Colorado, USA. ${ }^{4}$ Department of Organismic and Evolutionary Biology, Center for Systems Biology, Harvard University, Cambridge, Massachusetts, USA. " Vybion, Inc., Ithaca, New York, USA. ${ }^{6}$ Department of Paediatrics, Section of Infectious Disease, Tulane University, New Orleans, Louisiana, USA. ${ }^{7}$ Ministry of Health and Sanitation Workplace Health, Republic of Sierra Leone, Freetown, Sierra Leone. ${ }^{8}$ The Global Viral Forecasting Initiative, San Francisco, California, USA. ${ }^{9}$ Kenema Government Hospital Lassa Fever Ward, Kenema, Republic of Sierra Leone. ${ }^{10}$ University of Minnesota School of Medicine, Minneapolis, Minnesota, USA. " Broad Institute of Massachusetts Institute of Technology and Harvard, Cambridge, Massachusetts, USA.
\end{abstract}

\section{Authors' contributions}

Conceived and designed the experiments: LMB, MLB, KGA, RFG. Performed the experiments: $L M B, M L B, K G A, E M Z$. Analyzed the data/critical review of manuscript: LMB, MLB, KGA, JNG, JSS, JER, DSG, VNR, PCS, RFG. Contributed reagents/materials: IJM, LAH. Provided medical/outreach/case investigation support in Sierra Leone: LMM, JJB, DSG, VNR, MF. Wrote the manuscript: $L M B, M L B, K G A, J N G$, RFG. All authors have read and approved the final manuscript.

\section{Competing interests}

The authors declare that they have no competing interests.

Received: 18 October 2011 Accepted: 25 October 2011

Published: 25 October 2011

\section{Reference}

1. Luis M Branco, Matt L Boisen, Kristian G Andersen, Jessica N Grove, Lina M Moses, Ivana J Muncy, Lee A Henderson, John S Schieffellin, James E Robinson, James J Bangura, Donald S Grant, Vanessa N Raabe, Mbalu Fonnie, Eleina M Zaitsev, Pardis C Sabeti, Robert F Garry: Lassa hemorrhagic fever in a late term pregnancy from northern Sierra Leone with a positive maternal outcome: case report. Virology Journal 2011, 8:404.

doi:10.1186/1743-422X-8-480

Cite this article as: Branco et al:: Correction: Lassa hemorrhagic fever in a late term pregnancy from northern Sierra Leone with a positive maternal outcome: case report. Virology Journal 2011 8:480.

\footnotetext{
* Correspondence: rfgarry@tulane.edu

'Department of Microbiology and Immunology, Tulane University, New Orleans, Louisiana, USA

Full list of author information is available at the end of the article
}

Submit your next manuscript to BioMed Central and take full advantage of:

- Convenient online submission

- Thorough peer review

- No space constraints or color figure charges

- Immediate publication on acceptance

- Inclusion in PubMed, CAS, Scopus and Google Scholar

- Research which is freely available for redistribution
C Biomed Central

C 2011 Branco et al; licensee BioMed Central Ltd. This is an Open Access article distributed under the terms of the Creative Commons Attribution License (http://creativecommons.org/licenses/by/2.0), which permits unrestricted use, distribution, and reproduction in any medium, provided the original work is properly cited. 